in vivo $36: 40-48(2022)$

doi:10.21873/invivo.12674

Review

\title{
Ocular Side Effects of Aromatase Inhibitor Endocrine Therapy in Breast Cancer - A Review
}

\author{
DRAGOS SERBAN ${ }^{1,2}$, DANIEL OVIDIU COSTEA ${ }^{3,4}$, ANCA ZGURA $^{5,6}$, MIHAIL SILVIU TUDOSIE $^{7,8}$, \\ ANA MARIA DASCALU ${ }^{9,10}$, GABRIEL ANDREI GANGURA ${ }^{1,11}$, CATALIN GABRIEL SMARANDACHE $^{1,2}$, \\ ALEXANDRU DAN SABAU ${ }^{12,13}$, CORNELIU TUDOR ${ }^{2}$, MIHAI FAUR ${ }^{12,13}$, \\ ANDREEA CRISTINA COSTEA ${ }^{14}$, DANIELA STANA ${ }^{10}$, SIMONA ANDREEA BALASESCU ${ }^{2}$, \\ LAURA CARINA TRIBUS ${ }^{15,16}$ and CIPRIAN TANASESCU ${ }^{12,13}$ \\ ${ }^{1}$ Faculty of Medicine, Department of General Surgery \\ 'Carol Davila' University of Medicine and Pharmacy, Bucharest, Romania; \\ ${ }^{2} I V^{\text {th }}$ Department of Surgery, Emergency University Hospital, Bucharest, Romania; \\ ${ }^{3}$ Faculty of Medicine, Department of Clinical Surgical Disciplines I 'Ovidius' University, Constanta, Romania; \\ ${ }^{4}$ First Surgery Department, Emergency County Hospital, Constanta, Romania; \\ ${ }^{5}$ Department of Oncology, Radiology and Hematology, Faculty of Medicine, \\ 'Carol Davila' University of Medicine and Pharmacy, Bucharest, Romania; \\ ${ }^{6}$ Department of Oncology Radiotherapy, Institute of Oncology \\ 'Prof. Dr. Alexandru Trestioreanu', Bucharest, Romania; \\ ${ }^{7}$ Department of Orthopedia and Intensive care, Faculty of Medicine, \\ 'Carol Davila' University of Medicine and Pharmacy, Bucharest, Romania; \\ ${ }^{8}$ ICU II Toxicology, Clinical Emergency Hospital, Bucharest, Romania; \\ ${ }^{9}$ Department of ENT-Ophthalmology, Faculty of Medicine, \\ 'Carol Davila' University of Medicine and Pharmacy, Bucharest, Romania; \\ ${ }^{10}$ Ophthalmology Department, Emergency University Hospital, Bucharest, Romania; \\ ${ }^{11} 2^{\text {nd }}$ Department of Surgery, Emergency University Hospital, Bucharest, Romania; \\ ${ }^{12}$ Surgical Clinical Department, Faculty of Medicine, 'Lucian Blaga' University, Sibiu, Romania; \\ ${ }^{13}$ Department of Surgery, Sibiu County Emergency Clinical Hospital, Sibiu, Romania; \\ ${ }^{14}$ Nephrology and Dialysis Department, 'Diaverum' Clinic, Constanta, Romania; \\ ${ }^{15}$ Faculty of Medicine, Department of Internal Medicine Gastroenterology, \\ 'Carol Davila' University of Medicine and Pharmacy, Bucharest, Romania; \\ ${ }^{16}$ Gastroenterology Department, Emergency University Hospital Bucharest, Bucharest, Romania
}

\begin{abstract}
Background: Aromatase inhibitor therapy is currently the preferred choice in postmenopausal women with estrogen receptor positive breast cancer. This article reviews the ocular side effects of treatment with aromatase inhibitors (AIs)
\end{abstract}

This article is freely accessible online.

Correspondence to: Dr. Ana Maria Dascalu, Splaiul Independentei, nr. 169, 050098, Bucharest, Romania. Tel: +40 727402495, e-mail: ana.dascalu@umfcd.ro

Key Words: Breast cancer, endocrine therapy, aromatase inhibitors, ocular side-effects, dry eye, anastrozole, review. in patients with breast cancer. Materials and Methods: A comprehensive search was performed on PubMed, Web of Science and Google scholar. Results: After duplication removal, 14 clinical studies and 5 case reports, published between 2008 and 2021, were identified. Most frequently, AI treatment resulted in minor to moderate dry eye symptoms. "De novo" onset of Sjogren syndrome during AI therapy was also reported. Retinal and optic nerve side effects varied from mild, subclinical anatomic and functional impairment to severe decreased vision, secondary to hemi-central retinal artery occlusion, bilateral optic neuritis or uveitis with bilateral macular edema. Conclusion: Visual disturbances encountered during AI treatment may be underestimated. Ophthalmic screening is important for early detection and appropriate treatment. 
Breast cancer, through the large number of cases diagnosed annually worldwide, is a major public health problem of the female population. According to the World Health Organization (WHO) statistics, in 2020 there 2.3 million women were diagnosed with breast cancer and 685,000 died globally (1). Breast cancer is the most prevalent malignancy, with 7.8 million alive patients diagnosed in the last 5 years, being associated with the most lost disability-adjusted life years (DALYs) by women than any other type of cancer (2). The introduction of screening methods to identify breast cancer early at asymptomatic stages and the use of new methods of complex cancer treatment have allowed a significant reduction in mortality after the 1990s (3-5).

It is almost 50 years since the first studies showed that estrogens, labeled with radioactive substances, are preferentially concentrated in certain areas of the human body, including neoplastic breast tissue, substantiating the role of estrogen receptor (6). Most breast cancers are dependent on the expression of estrogen receptors (ER), progesterone $(\mathrm{PgR})$ or both, and their determination has predictive value and allows the selection of patients receiving hormone therapy as adjuvant therapy $(4,5)$.

If in the premenopausal period the main source of estrogen is the ovaries, in postmenopausal women estrogen is produced by the peripheral aromatization of androstenedione and testosterone to estrone and estradiol in extragonadal tissues, such as muscle, fatty tissue and breast. This explains the findings that, while in postmenopausal women the levels of serum estrogen are very low, the concentration of estrogen is 4-6-fold higher in breast tissue, which is relatively the same concentration as in premenopausal women, and it is even higher at the level of the breast tumor, by active uptake from the circulation and local aromatization in the tumor epithelial cells $(7,8)$.

Aromatase inhibitor therapy is currently the preferred choice in postmenopausal women with ER positive breast cancer. Three third-generation AIs were approved by the FDA as an adjuvant treatment for post-menopausal breast cancer patients: anastrozole $(1 \mathrm{mg} /$ day $)$ and letrozole $(2.5$ $\mathrm{mg}$ /day) can be used upfront for 5 years, while exemestane (25 mg/day) is approved for use after 2-3 years of tamoxifen use, for a total of 5 continuous years (9-13). Clinical trials have confirmed that aromatase inhibitors are more effective and better tolerated than tamoxifen in postmenopausal women with early or advanced ER-positive breast cancer.

Tamoxifen competitively blocks estrogen receptors, having an anti-estrogenic action at the breast level. In addition, it also acts as a partial estrogen agonist in other tissues, such as the bone, endometrium, and vascular endothelium, preventing osteoporosis, but also being a risk factor for endometrial cancer and thromboembolic events (14). Third generation aromatase inhibitors (AIs) are much more potent and specific than the first agent, aminoglutethimide, and have been approved for the hormonal treatment of breast cancer in postmenopausal women, decreasing estrogen to undetectable levels without influencing the levels of other classes of hormones $(8,9,15)$. When administered to premenopausal women, aromatase inhibitors should be associated with LHRH analogs for ovarian inhibition. Depending on the structure and type of interaction with the aromatase enzyme, they are divided into non-steroidal agents, such as anastrozole and letrozole, and steroidal, as exemestane. The inhibition of aromatase is reversible with letrozole and anastrozole but irreversible with exemestane (16).

Steroidal inhibitors resemble the structure of androstenedione and function by competing for the substrate binding sites of the enzyme. Steroid inhibitors are considered less toxic, but they have androgenic effects at high doses and poor oral bioavailability, with the exception of exemestane. The nonsteroidal inhibitors interact with the heme moiety of the CYP 450 prosthetic group of the aromatase molecule in a reversible manner. They have a good pharmacokinetic profile and lack hormonal properties, but are related to musculoskeletal disorders and bone demineralization (17).

Several clinical studies showed that treatment with aromatase inhibitors has generally lower side effects than tamoxifen $(8,18)$. Patients treated with AIs were reported to have lower risk of thrombotic events, endometrial cancer, uterine sarcoma and cerebral vascular diseases, side-effects that have been attributed to the partial estrogen-agonist action of tamoxifen. However, concerns have been raised about the long-term suppression of estrogen, which can result in aggressive menopause, and premature aging. Long term studies, on large cohorts of patients treated with anastrozole or letrozole vs. tamoxifen showed an increased risk of bone fracture, arthralgias, decrease in bone density and osteoporosis. Some relief could be offered by exemestane, due to its partial androgen agonist effects $(19,20)$.

The present article aims to document the ocular side effects related to the treatment of patients with breast cancer with aromatase inhibitors.

\section{Materials and Methods}

A comprehensive search was performed on PubMed, Web of Science and Google scholar, using the terms "breast cancer" AND "aromatase inhibitor" AND "ocular side effects". Additional search was performed using the alternative words for "aromatase inhibitor": "anastrozole", "letrozole" and "exemestane". For ocular side effects, further search was performed using the terms "ophthalmic side effects", "ophthalmic effects", "dry eye", "cornea*" and "retina*" All articles in English language for which full text could be obtained were included. Due to the limited number of publications on this topic, any reported side effects, either with proved causality or for which increased awareness was 
advised were included in the review. The type of study, number of patients, follow-up period, ocular side effects, ophthalmic treatment and outcomes were documented. Studies including patients with breast cancer treated with AIs not documenting ocular signs and symptoms were excluded.

\section{Results}

After duplication removal, a total of 14 clinical studies and 5 case reports were identified. They were published between 2008 and 2021 and reported ocular side effects in patients with breast cancer treated with aromatase inhibitors (Table I and Table II). There were 10 articles reporting impairment of the ocular surface (Table I), whereas 9 papers reported different neuro-retinal disturbances (Table II).

Dry eye and ocular surface abnormalities in AI treated breast cancer patients. Several clinical studies evidenced that hormonal therapy with aromatase inhibitors impacts ocular surface and Meibomian glands, resulting in a significant proportion of cases with dry eye disease, associated with meibomian disfunction. In 7 studies (21-27), the diagnosis of dry eye was based on ophthalmic examination, whereas in the study of Cuzick et al. (28), on self-reporting of signs and symptoms (Table I).

All studies included in the review reported decreased tear break-up time (TBUT), and Schirmer test with increased ocular surface disease index (OSDI) in breast cancer patients treated with AI, when compared with normal postmenopausal women and with breast cancer patients treated with tamoxifen. The OSDI questionnaire is a simple tool that is considered sensitive and specific for dry eye diseases, which can be selfadministered and used by health care professionals for screening $(21,31)$. An OSDI $>12$ was considered to indicate dry eye in all studies included in the review $(21,24,28)$. Among subjective signs reported by patients, the most frequent were foreign body sensation, blurred vision, redness, and photophobia $(23,25)$. The alteration of the lacrimal film was strongly related to deficiency in the lipid layer, due to decreased meibomian function and blepharitis.

Agin et al. (21) documented the alterations of the eyelids and ocular surface in a prospective study, with a mean follow-up period of 6 months, and found a significant decrease in the densities of endothelial cells, stromal and basal epithelial cells as well as of nerve fiber densities at the level of the cornea. However, whether these observations should be regarded as class side effects of AIs or a direct consequence of estrogen deprivation is still a subject of research. All studies except that of Gibson et al. (24), found a significant higher proportion of patients with dry eye signs and symptoms among those treated with AIs compared to normal postmenopausal women. Several cross-sectional studies based on ophthalmologic objective tests showed an incidence of dry eye syndrome of $29 \%$ to $46 \%$ of AI patients. Most cases exhibit minor to moderate symptoms, that responded favorably to local treatment with artificial tears and lubricants. Inglis et al. found a strong association between dry eye symptoms in patients treated with AIs and other side-effects such as dry vagina, pain or discomfort during intercourse and vaginal itching, which may suggest a common, potentially hormonal, mechanism leading to systemic mucosal dryness (26).

In the prospective study of Cuzick et al. (28), among the 1709 high-risk postmenopausal women who received anastrozole to prevent breast cancer (IBIS II study) $4 \%$ reported dry eye vs. $2 \%$ in the placebo group. This may suggest that self-reporting dry eye symptoms is much lower than the actual prevalence of dry eye disease when patients are questioned specifically about the symptoms. Active screening for dry eye disease signs and symptoms may help the patients to receive appropriate therapy, and so to improve their quality of life (26).

One particular side effect reported by Papathanasiou et al. (29) in a patient treated with exemestane was the presence of corneal intraepithelial microcysts, but with normal visual acuity and corneal sensitivity, and stable evolution during 1 year follow-up. One hypothesis discussed by the authors was related to the inhibitory effect of exemestane on limbal stem cell function. However, there are multiple causes of corneal impairment that may lead to corneal epithelial microcysts formation, such as chronic hypoxia in contact lens wearers, or corneal dystrophies, and a clear correlation between exemestane and the corneal lesions could not be proved.

Sjogren syndrome and AI. Several case series raised attention about the possible association between "de novo" onset of Sjogren Syndrome in patients with breast cancer treated with AI. Guidelli et al. (30) reported 3 cases of Sjogren syndrome in patients treated with anastrozole ( 2 patients) and letrozole (1 patient), exhibiting arthralgia, severely decreased lacrimal secretion measured by Schirmer test and histopathologic findings of labial salivary gland biopsy showing a moderate lymphoplasmacytic infiltrate ( $>1$ focus in $4 \mathrm{~mm}^{2}$ ), a severe ductal ectasia, and a mild interstitial fibrosis. In all cases the clinical signs appeared after the initiation of AI therapy.

Moreover, Laroche et al. (27), in a study of 19 patients with breast cancer treated with AIs and experiencing disabling joint pain with no underlying anatomical cause, found an increased frequency of sicca syndrome, in 10 out of 19 patients, and antinuclear autoantibodies (ANA) in 9 out 19 patients. However, as opposed to typical Sjogren syndrome, there was no biological inflammatory syndrome, and only moderate histopathological lesions of the accessory salivary glands (27). Consistent with these clinical findings, Shim et al. (32), in an aromatase-knockout (ArKO) experimental mouse model evidenced a lymphoproliferative 
in vivo $36: 40-48(2022)$

Table I. Ocular surface related side effects of treatment of breast cancer patients with aromatase inhibitors.

\begin{tabular}{|c|c|c|c|c|c|}
\hline $\begin{array}{l}\text { Study, } \\
\text { year }\end{array}$ & $\begin{array}{l}\text { Study } \\
\text { type }\end{array}$ & $\begin{array}{l}\text { No of patients } \\
\text { with breast cancer } \\
\text { (no of eyes); } \\
\text { no of controls }\end{array}$ & $\begin{array}{l}\text { Aromatase } \\
\text { inhibitor } \\
\text { used }\end{array}$ & $\begin{array}{l}\text { Duration of } \\
\text { follow-up }\end{array}$ & $\begin{array}{l}\text { Ocular } \\
\text { side effects } \\
\text { reported }\end{array}$ \\
\hline
\end{tabular}

\begin{tabular}{|c|c|c|c|c|c|}
\hline $\begin{array}{l}\text { Agin et al., } \\
2021 \text { (21) }\end{array}$ & Prospective & $13(13)$ & Anastrozole/letrozole & 6 months & $\begin{array}{c}\text { Ocular surface: } \\
\uparrow \text { OSDI; } \downarrow \text { TBUT, } \downarrow \text { Schirmer test } \\
\text { Meibomius glands: } \uparrow \text { meiboscores } \\
\text { Corneal structure: } \\
\downarrow \text { basal epithelial, stromal, endothelial } \\
\text { corneal cells densities; } \\
\downarrow \text { total number and nerves densities }\end{array}$ \\
\hline $\begin{array}{l}\text { Turaka et al., } \\
2013 \text { (22) }\end{array}$ & Retrospective & $41 ; 3091$ & $\begin{array}{l}\text { Anastrozole (22), } \\
\text { letrozole (15) and } \\
\text { exemestane (4) }\end{array}$ & $\begin{array}{r}22 \text { months } 20.3 \\
\text { (range } 0.1-65 \text { ) }\end{array}$ & $\begin{array}{c}\text { Dry eye symptoms: } 29 \% \text { vs. } 9.5 \% \\
\text { Blepharitis, Meibomius } \\
\text { gland disfunction }\end{array}$ \\
\hline $\begin{array}{l}\text { Bicer } \text { et al., } \\
2020 \text { (23) }\end{array}$ & $\begin{array}{l}\text { Prospective, } \\
\text { cross sectional }\end{array}$ & $\begin{array}{l}\text { Tamoxifen:50; } \\
\text { anastrozole, } \\
\text { letrozole: } 50 \text {; } \\
\text { controls: } 50\end{array}$ & $\begin{array}{l}\operatorname{tmx}: 20 \mathrm{mg} / \text { day } \\
\text { Anastrozole: } 1 \mathrm{mg} / \text { day } \\
\text { Letrozole: } 2,5 \mathrm{mg} / \text { day }\end{array}$ & - & $\begin{array}{c}\text { Increased OSDI and corneal staining: } \\
\text { AI }>\text { tmx }>\text { controls } \\
\text { ST scores higher in controls } \\
v s \text {. AI group } \\
\text { BUT higher in controls } \\
v s . \text { tmx and AI groups }\end{array}$ \\
\hline $\begin{array}{l}\text { Gibson et al., } \\
2020 \text { (24) }\end{array}$ & $\begin{array}{l}\text { Prospective, } \\
\text { cross sectional, } \\
\text { early-stage } \\
\text { breast cancer }\end{array}$ & $\begin{array}{l}52 ; 56 \\
\text { (postmenopausal, } \\
\text { age-matched) }\end{array}$ & $\begin{array}{c}\text { Letrozole } 38 \\
\text { Anastrozole } 7 \\
\text { Exemestane } 7\end{array}$ & - & $\begin{array}{c}\text { OSDI }>12 \text { in } 46 \% \text { AI group } \\
\text { vs. } 48 \% \text { in control group } \\
\text { PSQ higher in Ai group } \\
\text { Meibomius expressibility*: } \\
\text { lower in AI group } \\
\text { OSDI, MGD-14 or IOSS, BUT, } \\
\text { corneal staining - similar } \\
\text { between the } 2 \text { groups }\end{array}$ \\
\hline $\begin{array}{l}\text { Chatziralli et al., } \\
2016 \text { (25) }\end{array}$ & $\begin{array}{c}\text { Prospective, } \\
\text { early-stage } \\
\text { breast cancer }\end{array}$ & $41(80) ; 40(80)$ & $\begin{array}{c}\text { Letrozole, } 30(37.5) \\
\text { Anastrozole, } 27(33.8) \\
\text { Exemestane, } 23(28.7) \\
\text { Duration to first reported } \\
\text { symptom: } \\
13.2+/-12.6 \text { months }\end{array}$ & - & $\begin{array}{c}\text { Dry eye symptoms: } \\
\text { Blurred vision: } 47.5 \% \text { vs. } 7.5 \% \\
\text { Foreign body sensation: } 30 \% \text { vs. } 15 \% \\
\text { Tearing } 22.5 \% \text { vs. } 75 \% \\
\text { Dry eye signs: } \\
\text { Hyperemia: } 22.5 \% \text { vs. } 5 \% \\
\text { Superficial punctate keratitis: } \\
\text { 30\% vs. } 7.5 \% \\
\text { Meibomian gland dysfunction: } \\
42.5 \text { vs. } 12.5 \% \\
\text { Blepharitis } 75 \% \text { vs. } 25 \%\end{array}$ \\
\hline $\begin{array}{l}\text { Inglis et al., } \\
2015 \text { (26) }\end{array}$ & & $93 ; 100$ & $\begin{array}{c}\text { Anastrozole } 45 \\
\text { Letrozole } 39 \\
\text { Exemestane } 9\end{array}$ & - & $\begin{array}{c}\text { Dry eye prevalence } \\
(\text { OSDI }>12): 35 \% \text { vs. } 18 \%\end{array}$ \\
\hline $\begin{array}{l}\text { Laroche et al. } \\
2007,(27)\end{array}$ & Prospective & $\begin{array}{c}19 \text { patients with } \\
\text { breast cancer treated } \\
\text { with } \mathrm{AI} \text { and joint pain }\end{array}$ & $\begin{array}{c}\text { Anastrozole } \\
\text { letrozole }\end{array}$ & 6 months & $\begin{array}{l}10 \text { patients: sicca syndrome } \\
\text { ( } 7 \text { patients - Sjogren } \\
\text { syndrome, ANA+) }\end{array}$ \\
\hline $\begin{array}{l}\text { Cuzick et al. } \\
\text { 2013, (28) }\end{array}$ & $\begin{array}{l}\text { International, } \\
\text { double-blind, } \\
\text { randomized } \\
\text { placebo-controlled } \\
\text { trial IBIS II }\end{array}$ & $1920 ; 1944$ & Anastrozole $1 \mathrm{mg} / \mathrm{zi}$ & 5 years & $\begin{array}{c}\text { Dry eyes } \\
83(4 \%) \text { vs. } 58(2 \%) \\
\text { Risk ratio } 1 \times 45(1 \times 04-2 \times 01) \\
\text { Conjunctivitis } \\
12(1 \%) \text { vs. } 5(<1 \%) \\
\text { risk ratio } 2 \times 43(0 \times 86-6 \times 88)\end{array}$ \\
\hline $\begin{array}{l}\text { Papathanassiou } \\
\text { et al., } 2010 \text { (29) }\end{array}$ & Case report & $1(2)$ & Exemestane & 1 year & $\begin{array}{l}\text { Corneal intraepithelial } \\
\text { microcysts, normal Schirmer's } \\
\text { test, VA, and corneal sensitivity }\end{array}$ \\
\hline $\begin{array}{l}\text { Guidelli } \text { et al. } \\
\text { 2013, (30) }\end{array}$ & Case series & $3(6)$ & $\begin{array}{l}\text { Anastrozole } 2 \\
\text { Letrozole } 1\end{array}$ & - & $\begin{array}{c}\text { Sjogren Syndrome } \\
\text { Abnormal low Schirmer test } \\
(4 \mathrm{~mm} \text { in one patient; } 2 \mathrm{~mm} \\
\text { in } 2 \text { patients })\end{array}$ \\
\hline
\end{tabular}

*The number of meibomian glands yielding liquid secretion. 
Table II. Retinal and optic nerve side effects of treatment of breast cancer patients with aromatase inhibitor.

\begin{tabular}{|c|c|c|c|c|c|}
\hline Author, year & Study type & $\begin{array}{l}\text { No of patients; } \\
\text { controls }\end{array}$ & AI used & $\begin{array}{l}\text { Side-effects reported } \\
\quad(p<0.05)\end{array}$ & Treatment \\
\hline $\begin{array}{l}\text { Moschos } \\
\text { et al., } 2015 \text { (9) }\end{array}$ & $\begin{array}{l}\text { Cross-sectional, } \\
\text { early-stage } \\
\text { breast cancer }\end{array}$ & $49(80) ; 40(80)$ & $\begin{array}{c}\text { Letrozole } 30(37.5) \\
\text { Anastrozole } 27(33.8) \\
\text { Exemestane } 23(28.7)\end{array}$ & $\begin{array}{c}\text { OCT: lower average, } \\
\text { sup and inf RNFL; } \\
\text { mf-ERG: } \\
\downarrow \text { P100 amplitude } \\
\uparrow \mathrm{P} 100 \text { latency; } \\
\downarrow \text { Retinal response density } \\
\text { (nV/deg2) in ring } 1 \text { (fovea) } \\
\text { and ring } 2 \text { (parafoveal) }\end{array}$ & None \\
\hline $\begin{array}{l}\text { Eisner } \text { et al., } \\
2007 \text { (33) }\end{array}$ & $\begin{array}{l}\text { Comparative } \\
\text { study }\end{array}$ & $20 ; 34 ; 32$ & $\begin{array}{c}\text { Anastrozole }(1 \mathrm{mg} / \text { daily }) \\
\text { Tamoxifen } 20 \mathrm{mg} / \text { daily, } \\
<2 \text { years }) \\
\text { controls }\end{array}$ & $\begin{array}{l}\text { Optic disc subclinical } \\
\text { swelling in Tmx group } v s \text {. } \\
\text { anastrozole and normal; } \\
\text { optic cup volumes, } \\
\text { maximum optic cup depths, } \\
\text { and cup/disk area ratios } \\
\text { (measured by HRT II) } \\
\text { were each significantly } \\
\text { smaller for the tamoxifen } \\
\text { users than for the } \\
\text { anastrozole users; }\end{array}$ & None \\
\hline $\begin{array}{l}\text { Epstein } \text { et al., } \\
2009(36)\end{array}$ & 2 Case report & $\begin{array}{l}2 \text { patients } \\
\text { with early-stage } \\
\text { breast cancer } \\
\text { and myopia }\end{array}$ & $\begin{array}{l}\text { Case 1: Letrozole, } \\
\text { changed to Exemestane } \\
\text { after } 5 \text { months due to } \\
\text { musculoskeletal pain } \\
\text { Case 2: anastrozole, } \\
\text { changed to exemestane } \\
\text { after } 2 \text { years due to } \\
\text { cholesterol metabolism } \\
\text { impairment }\end{array}$ & $\begin{array}{l}\text { Case 1: Retinal detachment, } \\
\text { Case 2: macular hole } \\
\text { No causality relationship } \\
\text { was established, but } \\
\text { raised awareness; }\end{array}$ & $\begin{array}{l}\text { Vitreoretinal surgery; } \\
\text { AI was discontinued }\end{array}$ \\
\hline $\begin{array}{l}\text { Moschos et al., } \\
2013 \text { (37) }\end{array}$ & Case-report & 1 & $\begin{array}{c}\text { letrozole } 2.5-\mathrm{mg} / \mathrm{day} \\
3 \text { years }\end{array}$ & $\begin{array}{l}\text { Both eyes: decreased } \\
\text { response in mf-ERG } \\
\text { RE: macular edema } \\
\text { documented by OCT } \\
\text { and AFG }\end{array}$ & $\begin{array}{c}\text { Intravitreal } 0.05-\mathrm{ml} / 0.5-\mathrm{mg} \\
\text { ranibizumab; AI } \\
\text { was discontinued }\end{array}$ \\
\hline $\begin{array}{l}\text { Karagoz et al., } \\
2009(38)\end{array}$ & Case report & 1 & Anastrozole, 3 years & $\begin{array}{l}\text { Hemi-central arterial } \\
\text { retinal occlusion } \\
\text { Comorbidities: } \\
\text { arterial hypertension, DM }\end{array}$ & $\begin{array}{c}\text { AI discontinued; } \\
\text { Hyperbaric O2 therapy, } \\
\text { but with no } \\
\text { visual improvement }\end{array}$ \\
\hline $\begin{array}{l}\text { Coppes et al., } \\
2014(34)\end{array}$ & Case report & 1 & Anastrozole & $\begin{array}{c}\text { Bilateral optic neuritis } \\
\text { RE }>\text { LE; } \\
\text { Comorbidities: } \\
\text { Hypertension, asthma } \\
\text { Outcome: partial optic } \\
\text { atrophy in RE; total } \\
\text { recovery in LE }\end{array}$ & $\begin{array}{l}\text { iv and oral corticosteroids; } \\
\text { discontinued AI, switch to } \\
\text { exemestane } 25 \mathrm{mg} \text { daily } \\
\text { after } 6 \text { months }\end{array}$ \\
\hline $\begin{array}{l}\text { Sathiamoorthi } \\
\text { et al., } \\
2018(35)\end{array}$ & Case report & 1 & $\begin{array}{l}\text { Anastrozole, } \\
>2 \text { years }\end{array}$ & $\begin{array}{l}\text { RE: uveitis and macular } \\
\text { edema; bilateral epiretinal } \\
\text { membranes }\end{array}$ & $\begin{array}{l}\text { Topic CS for one month } \\
\text { Total remission }\end{array}$ \\
\hline $\begin{array}{l}\text { Eisner } \text { et al., } \\
2009 \text { (39) }\end{array}$ & $\begin{array}{l}\text { Cross sectional, } \\
\text { comparative } \\
\text { study }\end{array}$ & $\begin{array}{l}27 \text { (anastrozole group); } \\
25 \text { (tmx group); } \\
40 \text { (Control) }\end{array}$ & $\begin{array}{l}1 \mathrm{mg} \text { anastrozole } \\
\text { daily; } 20 \mathrm{mg} \operatorname{tmx} \\
\text { daily }\end{array}$ & $\begin{array}{l}\text { Increased vitreo-retinal } \\
\text { traction; } \\
\uparrow \text { susceptibility to } \\
\text { myopia-induced PVDs }\end{array}$ & None \\
\hline $\begin{array}{l}\text { Eisner } \text { et al., } \\
2008,(40)\end{array}$ & $\begin{array}{l}\text { Cross sectional, } \\
\text { comparative } \\
\text { study }\end{array}$ & $\begin{array}{c}35 \text { (anastrozole group); } \\
38 \text { (tmx group); } \\
53 \text { (control) }\end{array}$ & $\begin{array}{c}1 \mathrm{mg} \text { anastrozole } \\
\text { daily; } 20 \mathrm{mg} \text { tmx daily }\end{array}$ & $\begin{array}{c}\text { Retinal hemorrhages: } \\
4 \text { - anastrozole group } \\
1 \text { (historically) - tmx group } \\
\text { 0-controls }\end{array}$ & No info \\
\hline
\end{tabular}

mf-ERG: Multifocal electroretinogram; CS: corticosteroids; ANA: antinuclear autoantibodies; PVDs: posterior vitreous detachments; tmx: tamoxifen. 
autoimmune infiltration similar to Sjogren Syndrome, which suggests the protective role of estrogen.

AI side effects at the level of the retina and optic disk. Various changes were reported at the neuroretinal level in breast cancer patients treated with AIs, ranging from mild, subclinical anatomic and functional impairment $(9,33)$, to severe decreased visual acuity resulting in permanent disabling visual sequelae, secondary to hemi-central retinal artery occlusion, bilateral optic neuritis (34) and uveitis with bilateral macular edema (35) (Table II).

Moschos et al. (9) found a lower thickness of the mean retinal nerve fiber layer (RNFL) measured by optical coherence tomography, when compared to normal agematched postmenopausal women. The anatomical subclinical changes were correlated with functional changes on multifocal electroretinogram (mfERG): decreased amplitude and increased latency of P100. The decreased functionality seems to affect mostly the foveolar and perifoveolar region. Moschos et al. (9) found not significant differences between the 3 AIs (anastrozole, letrozole and exemestane) in terms of average RNFL decrease, decreased P 100 amplitude, and increased latency. However, in the exemestane group, a decreased temporal RNFL and increased latency of P1 (in ring 1) were found, suggesting early subclinical decrease in macular function, and degeneration in the papillomacular bundle.

In a study focusing on optic cup and cup/disk ratio, Eisner et al. (33) found that treatment with AIs had no effect on cup volume and cup disk ratio, whereas tamoxifen use was related with decrease cup volume, as an indicator of the subclinical edema of the optic nerve fibers.

There is clinical evidence that anastrozole use in breast cancer might lead to increase vitreo-retinal traction. Eisner et al. (39) raised awareness about the susceptibility of posterior vitreous detachment in myopic patients treated with AIs. Epstein et al. (36) reported 2 cases of myopic patients treated with exemestane that developed retinal detachment and macular hole that required vitreoretinal surgery. An interesting study by Eisner et al. (40) found an increased incidence of retinal hemorrhages in patients treated with anastrozole $v s$. tamoxifen or postmenopausal controls. The possible explanations might be related to the estrogen depletion of the vasculature or increased vitreoretinal traction forces. However, 2 out of 4 patients who experienced retinal hemorrhages were also treated with bisphosphonate and aspirin for the musculoskeletal side-effects of aromatase inhibitor therapy, which may also cause bleeding (40).

\section{Discussion}

Alfa and beta estrogen receptors have been identified in the retina and choroid, and also at the level of the lacrimal glands, including Meibomian gland conjunctival and corneal surface, but their physiological roles are still a subject of research $(41,42)$. Dry eye incidence increases with age, and is significantly higher in postmenopausal women. However, clinical studies found that the incidence of dry eye was higher in postmenopausal women taking estrogens supplements compared to those not taking hormonal medication or using estrogen-progesterone combinations $(43,44)$. Recent studies showed that the health of ocular surface and a normal lacrimal film depend on a delicate balance between androgens and estrogens. Estrogens promote the maturation of the superficial cells in the conjunctiva, influence the aqueous component of the lacrimal layer and have a trophic role at the level of the cornea. On the other hand, estrogens might have a proinflammatory action at the level of ocular surface. Experimental studies documented that at the level of the cornea, 17 beta estradiol induces an increase in the mRNA levels of IL- $1 \beta$, IL-6, IL-8, and GM-CSF, suggesting it may favor inflammation associated with dry eye disease (45). Androgens have an anti-inflammatory effect and stimulate meibomian gland secretion contributing to the lipid layer of the lacrimal film, which ensures stability and decreased evaporation, protecting the ocular surface (46).

Treatment of breast cancer patients with Ais led to significant decrease of peripheral estrogen levels, depleting the ocular surface from the trophic protective effects of estrogens. Although in most cases, the dry eye disease and Meibomian gland disfunction is minor to moderate, an active screening by OSDI may improve patients' quality of life by indicating the necessity for treatment to reduce visual impairment (24).

The ocular side effects of high dose and low dose of 20 $\mathrm{mg}$ /day tamoxifen in patients with breast cancer are well studied (47). While cataract induced by tamoxifen is still a controversy, the American Association of Ophthalmology recommends periodic ophthalmologic check-ups to identify specific retinal signs of tamoxifen related toxicity, such as deposits of intraretinal crystals, macular edema, retinal hemorrhages, optic neuritis, and tamoxifen-induced retinopathy $(47,48)$.

The ATAC (arimidex, tamoxifen alone or in combination) trial has demonstrated that anastrozole resulted in a clinically significant reduction in thromboembolic events; 4.1, 2.0, 2.8, and $1.6 \%$ of patients under anastrozole treatment suffered thromboembolic events in terms of coronary, cerebrovascular, venous, and deep venous systems, respectively $(10,38)$.

There is limited evidence regarding the possible retinal side-effects of the treatment of breast cancer patients with aromatase inhibitors. Whether they are a consequence of estrogen deprivation, a medication side effect or both, is still a subject for further longitudinal studies, to document the specific changes and their evolution in time.

Estrogens play multiple regulatory roles in retina and ocular blood flow (49-51). Experimental studies documented 
a protective role of estrogens on retinal pigment epithelium cells against oxidative stress, a trophic role via expression of VEGF and its receptors, and anti-inflammatory effects by attenuating Il-6 response to LPS or by modulating ocular blood flow $(49,50)$. In animal models, estrogen deficiency has been reported to lead to increased levels of tumor necrosis factor-alpha (TNF- $\alpha$ ) and endothelin-1, leading to a possible proinflammatory state in the vasculature (34).

The main reported side-effects related to AI use are, besides reduced bone mineralization, AI-induced musculoskeletal symptoms (AIMSS), characterized as a distinct entity first in 2001. Signs and symptoms include: joint pain and myalgia, stiffness, tenosynovitis, carpian tunnel syndrome and muscle weakness, and may involve both central and peripheric joints. In the systematic review of Beckwee et al., the incidence of AIMSS was found to be between $20 \%$ and $74 \%$, with onset of symptoms after a mean period of 6 weeks and a peak of intensity around 6 months (52). In a comprehensive review on the ocular effects of breast cancer medications, Eisner et al. (50) raised the possibility that measured changes in vitreo-retinal traction might be useful in helping to mark changes in joints that accompany the development of AI-induced arthralgia, based on the similar biochemical structure of the joints and vitreous body. However, further studies are needed to confirm the statistical significance of these correlations.

The present review presents the clinical evidence regarding ocular disorders related to the treatment of breast cancer with AIs. There are limitations regarding the differences in methodology used, the small number of patients included in the clinical studies, except of Cuzick et al. (28). Moreover, only few studies are longitudinal, and described the dynamics of ocular changes during AI treatment. Case reports may raise awareness for possible side effects, but they have limited statistical value in describing the incidence of the specific event and the possible associated risk factors.

\section{Conclusion}

Ocular side effects related to AI use in breast cancer patients may appear, but they seem to be less frequent and severe when compared to tamoxifen. Dry eye symptoms may be successfully treated with artificial tears and lubricants in most cases and they do not require interruption of therapy. In more severe events, such as retinal detachment, recurrent uveitis or hemiretinal artery occlusion, management includes stopping or switching the causative aromatase inhibitor agent, in cooperation with the oncological team. Further evidence from longitudinal studies, performed on a larger number of patients are needed to document the incidence of possible ocular side effects of aromatase inhibitors used in breast cancer therapy. However, many visual disturbances may be underestimated or considered as a sign of aging and ignored by patients when self-reporting the possible side effects of the hormonal therapy. A more focused ophthalmologic screening may improve patients' quality of life.

\section{Conflicts of Interest}

The Authors declare no conflicts of interest in relation to this study.

\section{Authors' Contributions}

DrS, AMD, AZ, MST, DOC, ADS, SAB and DaS contributed to the conception and design of this study. GAG, ACC, DOC, MST, LCT, CGS, CoT, MF and CiT were responsible for the data collection and analysis. DrS, AMD, GAG, SAB, CGS, ACC, CiT and DaS were in charge of drafting the manuscript. ADS, MF, LCT, AZ, MST, DOC, DrS, CoT, revised the manuscript critically for important intellectual content. The final version was read and approved by all the Authors.

\section{References}

1 Sung H, Ferlay J, Siegel RL, Laversanne M, Soerjomataram I, Jemal A and Bray F: Global cancer statistics 2020: GLOBOCAN estimates of incidence and mortality worldwide for 36 cancers in 185 countries. CA Cancer J Clin 71(3): 209-249, 2021. PMID: 33538338. DOI: $10.3322 /$ caac. 21660

2 Breast cancer. World Health Organization. Available at: https://www.who.int/news-room/fact-sheets/detail/breast-cancer [Last accessed on September 10, 2021]

3 Hendrick RE, Baker JA and Helvie MA: Breast cancer deaths averted over 3 decades. Cancer 125(9): 1482-1488, 2019. PMID: 30740647. DOI: $10.1002 / \mathrm{cncr} .31954$

4 Dafni U, Tsourti Z and Alatsathianos I: Breast cancer statistics in the European Union: Incidence and survival across European countries. Breast Care (Basel) 14(6): 344-353, 2019. PMID: 31933579. DOI: $10.1159 / 000503219$

5 Cardoso F, Kyriakides S, Ohno S, Penault-Llorca F, Poortmans P, Rubio IT, Zackrisson S, Senkus E and ESMO Guidelines Committee: Early breast cancer: ESMO Clinical Practice Guidelines for diagnosis, treatment and follow-up $\dagger$. Ann Oncol 30(8): 1194-1220, 2019. PMID: 31161190. DOI: 10.1093/ annonc/mdz173

6 Fuentes $\mathrm{N}$ and Silveyra P: Estrogen receptor signaling mechanisms. Adv Protein Chem Struct Biol 116: 135-170, 2019. PMID: 31036290. DOI: 10.1016/bs.apcsb.2019.01.001

7 Smith IE and Dowsett M: Aromatase inhibitors in breast cancer. N Engl J Med 348(24): 2431-2442, 2003. PMID: 12802030. DOI: $10.1056 /$ NEJMra023246

8 Narashimamurthy J, Rao AR and Sastry GN: Aromatase inhibitors: a new paradigm in breast cancer treatment. Curr Med Chem Anticancer Agents 4(6): 523-534, 2004. PMID: 15579017. DOI: $10.2174 / 1568011043352669$

9 Moschos MM, Chatziralli IP, Sergentanis T, Zagouri F, Chrysikos D, Ladas I and Zografos G: Electroretinographic and optical coherence tomography findings in breast cancer patients using aromatase inhibitors. Cutan Ocul Toxicol 35(1): 13-20, 2016. PMID: 25597370. DOI: 10.3109/15569527.2014.1003267 
10 Arimidex, Tamoxifen, Alone or in Combination (ATAC) Trialists' Group., Forbes JF, Cuzick J, Buzdar A, Howell A, Tobias JS and Baum M: Effect of anastrozole and tamoxifen as adjuvant treatment for early-stage breast cancer: 100-month analysis of the ATAC trial. Lancet Oncol 9(1): 45-53, 2008. PMID: 18083636. DOI: 10.1016/S1470-2045(07)70385-6

11 Goss PE, Ingle JN, Martino S, Robert NJ, Muss HB, Piccart MJ, Castiglione M, Tu D, Shepherd LE, Pritchard KI, Livingston RB, Davidson NE, Norton L, Perez EA, Abrams JS, Therasse P, Palmer MJ and Pater JL: A randomized trial of letrozole in postmenopausal women after five years of tamoxifen therapy for early-stage breast cancer. N Engl J Med 349(19): 1793-1802, 2003. PMID: 14551341. DOI: 10.1056/ NEJMoa032312

12 Coombes RC, Hall E, Gibson LJ, Paridaens R, Jassem J, Delozier T, Jones SE, Alvarez I, Bertelli G, Ortmann O, Coates AS, Bajetta E, Dodwell D, Coleman RE, Fallowfield LJ, Mickiewicz E, Andersen J, Lønning PE, Cocconi G, Stewart A, Stuart N, Snowdon CF, Carpentieri M, Massimini G, Bliss JM, van de Velde $\mathrm{C}$ and Intergroup Exemestane Study: A randomized trial of exemestane after two to three years of tamoxifen therapy in postmenopausal women with primary breast cancer. $\mathrm{N}$ Engl $\mathrm{J}$ Med 350(11): 1081-1092, 2004. PMID: 15014181. DOI: 10.1056/NEJMoa040331

13 Tomao F, Spinelli G, Vici P, Pisanelli GC, Cascialli G, Frati L, Panici PB and Tomao S: Current role and safety profile of aromatase inhibitors in early breast cancer. Expert Rev Anticancer Ther 11(8): 1253-1263, 2011. PMID: 21916579. DOI: $10.1586 /$ era.11.96

14 Martinkovich S, Shah D, Planey SL and Arnott JA: Selective estrogen receptor modulators: tissue specificity and clinical utility. Clin Interv Aging 9: 1437-1452, 2014. PMID: 25210448. DOI: $10.2147 /$ CIA.S66690

15 Poole R and Paridaens R: The use of third-generation aromatase inhibitors and tamoxifen in the adjuvant treatment of postmenopausal patients with hormone-dependent breast cancer: evidence based review. Curr Opin Oncol 19(6): 564-572, 2007. PMID: 17906453. DOI: 10.1097/CCO.0b013e3282f1c523

16 Geisler J: Differences between the non-steroidal aromatase inhibitors anastrozole and letrozole-of clinical importance? $\mathrm{Br}$ J Cancer 104(7): 1059-1066, 2011. PMID: 21364577. DOI: $10.1038 /$ bjc. 2011.58

17 Hong Y, Rashid R and Chen S: Binding features of steroidal and nonsteroidal inhibitors. Steroids 76(8): 802-806, 2011. PMID: 21420422. DOI: $10.1016 /$ j.steroids.2011.02.037

18 Mouridsen HT: Aromatase inhibitors in advanced breast cancer Semin Oncol 31(6 Suppl 12): 3-8, 2004. PMID: 15719595. DOI: 10.1053/j.seminoncol.2004.09.020

19 Fabian CJ: The what, why and how of aromatase inhibitors: hormonal agents for treatment and prevention of breast cancer. Int J Clin Pract 61(12): 2051-2063, 2007. PMID: 17892469. DOI: $10.1111 / \mathrm{j} .1742-1241.2007 .01587 . x$

20 Howell A, Cuzick J, Baum M, Buzdar A, Dowsett M, Forbes JF, Hoctin-Boes G, Houghton J, Locker GY, Tobias JS and ATAC Trialists' Group: Results of the ATAC (Arimidex, Tamoxifen, Alone or in Combination) trial after completion of 5 years' adjuvant treatment for breast cancer. Lancet 365(9453): 60-62, 2005. PMID: 15639680. DOI: 10.1016/S0140-6736(04)17666-6

21 Ağın A, Kocabeyoglu S, Yucel Gencoglu A, Aksoy S, Karakaya $\mathrm{J}$ and Irkec M: The effects of systemic aromatase inhibitors on meibomian glands and corneal structure. Eye (Lond), 2021. PMID: 34117393. DOI: 10.1038/s41433-021-01612-Z

22 Turaka K, Nottage JM, Hammersmith KM, Nagra PK and Rapuano CJ: Dry eye syndrome in aromatase inhibitor users. Clin Exp Ophthalmol 41(3): 239-243, 2013. PMID: 22957932. DOI: $10.1111 / \mathrm{j} .1442-9071.2012 .02865 . x$

23 Bicer T, Imamoglu GI, Dogan AS, Avarisli NA, Kabatas N, Bicer BK and Gurdal C: The effects of adjuvant hormonotherapy on tear functions in patients with breast cancer. Int Ophthalmol 40(8): 2077-2083, 2020. PMID: 32333340. DOI: 10.1007/s 10792-020-01384-7

24 Gibson E, Stapleton F, Dear R, Wolffsohn JS and Golebiowski B: Dry eye signs and symptoms in aromatase inhibitor treatment and the relationship with pain. Ocul Surf 18(1): 108-113, 2020. PMID: 31669349. DOI: 10.1016/j.jtos.2019.10.008

25 Chatziralli I, Sergentanis T, Zagouri F, Chrysikos D, Ladas I, Zografos GC and Moschos M: Ocular surface disease in breast cancer patients using aromatase inhibitors. Breast J 22(5): 561563, 2016. PMID: 27296769. DOI: 10.1111/tbj.12633

26 Inglis H, Boyle FM, Friedlander ML and Watson SL: Dry eyes and AIs: If you don't ask you won't find out. Breast 24(6): 694698, 2015. PMID: 26422124. DOI: 10.1016/j.breast.2015.08.008

27 Laroche M, Borg S, Lassoued S, De Lafontan B and Roché H: Joint pain with aromatase inhibitors: abnormal frequency of Sjögren's syndrome. J Rheumatol 34(11): 2259-2263, 2007. PMID: 17937464.

28 Cuzick J, Sestak I, Forbes JF, Dowsett M, Knox J, Cawthorn S, Saunders C, Roche N, Mansel RE, von Minckwitz G, Bonanni B, Palva T, Howell A and IBIS-II investigators: Anastrozole for prevention of breast cancer in high-risk postmenopausal women (IBIS-II): an international, double-blind, randomised placebocontrolled trial. Lancet 383(9922): 1041-1048, 2014. PMID: 24333009. DOI: 10.1016/S0140-6736(13)62292-8

29 Papathanassiou M, Nikita E, Theodossiadis P, Theodossiadis GP and Vergados I: Exemestane-induced corneal epithelial changes. Cutan Ocul Toxicol 29(3): 209-211, 2010. PMID: 20470238. DOI: $10.3109 / 15569521003775013$

30 Guidelli GM, Martellucci I, Galeazzi M, Francini G and Fioravanti A: Sjögren's syndrome and aromatase inhibitors treatment: is there a link? Clin Exp Rheumatol 31(4): 653-654, 2013. PMID: 23558055

31 Schiffman RM, Christianson MD, Jacobsen G, Hirsch JD and Reis BL: Reliability and validity of the Ocular Surface Disease Index. Arch Ophthalmol 118(5): 615-621, 2000. PMID: 10815152. DOI: 10.1001/archopht.118.5.615

32 Shim GJ, Warner M, Kim HJ, Andersson S, Liu L, Ekman J, Imamov O, Jones ME, Simpson ER and Gustafsson JA: Aromatase-deficient mice spontaneously develop a lymphoproliferative autoimmune disease resembling Sjogren's syndrome. Proc Natl Acad Sci U.S.A. 101(34): 12628-12633, 2004. PMID: 15314222. DOI: 10.1073/pnas.0405099101

33 Eisner A, Toomey MD, Falardeau J, Samples JR and Vetto JT: Differential effects of tamoxifen and anastrozole on optic cup size in breast cancer survivors. Breast Cancer Res Treat 106(2): 161-170, 2007. PMID: 17260092. DOI: 10.1007/s10549-0069486-3

34 Coppes OJ, Lukas RV, Fleming GF, Nichols J, Tenney M and Bernard J: Bilateral optic disc swelling following anastrozole therapy. Neuroophthalmology 38(5): 268-271, 2014. PMID: 27928312. DOI: $10.3109 / 01658107.2014 .924968$ 
35 Sathiamoorthi S, Ruddy KJ and Bakri SJ: Association of uveitis and macular edema with anastrozole therapy. JAMA Ophthalmol 136(7): 837-839, 2018. PMID: 29800041. DOI: 10.1001/ jamaophthalmol.2018.1700

36 Epstein RJ: Visual impairment in myopic patients with breast cancer receiving adjuvant therapy with aromatase inhibitors. Clin Breast Cancer 9(3): 184-186, 2009. PMID: 19661043. DOI: 10.3816/CBC.2009.n.030

37 Moschos MM, Chatziralli IP, Zagouri F and Zografos GC: Macular oedema due to letrozole: a first case report. Clin Exp Optom 95(6): 646-650, 2012. PMID: 22882318. DOI: 10.1111/j.1444-0938.2012.00771.x

38 Karagöz B, Ayata A, Bilgi O, Uzun G, Unal M, Kandemir EG, Ozgün A and Türken O: Hemicentral retinal artery occlusion in a breast cancer patient using anastrozole. Onkologie 32(7): 421423, 2009. PMID: 19556821. DOI: 10.1159/000218369

39 Eisner A, Thielman EJ, Falardeau J and Vetto JT: Vitreo-retinal traction and anastrozole use. Breast Cancer Res Treat 117(1): 916, 2009. PMID: 18712596. DOI: 10.1007/s10549-008-0156-5

40 Eisner A, Falardeau J, Toomey MD and Vetto JT: Retinal hemorrhages in anastrozole users. Optom Vis Sci 85(5): 301-308, 2008. PMID: 18451730. DOI: 10.1097/OPX.0b013e31816bea3b

41 Spelsberg H, Klueppel M, Reinhard T, Glaeser M, Niederacher D, Beckmann MW and Sundmacher R: Detection of oestrogen receptors (ER) alpha and beta in conjunctiva, lacrimal gland, and tarsal plates. Eye (Lond) 18(7): 729-733, 2004. PMID: 14739915. DOI: $10.1038 /$ sj.eye.6701314

42 Barabino S, Chen Y, Chauhan S and Dana R: Ocular surface immunity: homeostatic mechanisms and their disruption in dry eye disease. Prog Retin Eye Res 31(3): 271-285, 2012. PMID: 22426080. DOI: 10.1016/j.preteyeres.2012.02.003

43 Schaumberg DA, Buring JE, Sullivan DA and Dana MR: Hormone replacement therapy and dry eye syndrome. JAMA 286(17): 2114-2119, 2001. PMID: 11694152. DOI: 10.1001/ jama.286.17.2114

44 AlAwlaqi A and Hammadeh M: Examining the relationship between hormone therapy and dry-eye syndrome in postmenopausal women: a cross-sectional comparison study. Menopause 23(5): 550-555, 2016. PMID: 27003590. DOI: 10.1097/GME.0000000000000570
45 Suzuki T, Schirra F, Richards SM, Jensen RV and Sullivan DA: Estrogen and progesterone control of gene expression in the mouse meibomian gland. Invest Ophthalmol Vis Sci 49(5): 1797-1808, 2008. PMID: 18436814. DOI: 10.1167/iovs.07-1458

46 Chhadva P, Goldhardt R and Galor A: Meibomian gland disease: The role of gland dysfunction in dry eye disease. Ophthalmology 124(11S): S20-S26, 2017. PMID: 29055358. DOI: 10.1016/ j.ophtha.2017.05.031

47 Noureddin BN, Seoud M, Bashshur Z, Salem Z, Shamseddin A and Khalil A: Ocular toxicity in low-dose tamoxifen: a prospective study. Eye (Lond) 13 (Pt 6): 729-733, 1999. PMID: 10707134. DOI: $10.1038 /$ eye 1999.217

48 Watch for Ocular Effects of Breast Cancer Drugs. American Academy of Ophthalmology. Available at: https://www.aao.org/ eyenet/article/watch-ocular-effects-of-breast-cancer-drugs [Last accessed on October 4, 2021]

49 Nuzzi R, Scalabrin S, Becco A and Panzica G: Gonadal hormones and retinal disorders: A review. Front Endocrinol (Lausanne) 9: 66, 2018. PMID: 29551993. DOI: 10.3389/ fendo.2018.00066

50 Eisner A and Luoh SW: Breast cancer medications and vision: effects of treatments for early-stage disease. Curr Eye Res 36(10): 867-885, 2011. PMID: 21819259. DOI: 10.3109/ 02713683.2011 .594202

51 Almafreji I, Smith C and Peck F: Review of the literature on ocular complications associated with aromatase inhibitor use. Cureus 13(8): e17565, 2021. PMID: 34646621. DOI: 10.7759/ cureus. 17565

52 Beckwée D, Leysen L, Meuwis K and Adriaenssens N: Prevalence of aromatase inhibitor-induced arthralgia in breast cancer: a systematic review and meta-analysis. Support Care Cancer 25(5): 1673-1686, 2017. PMID: 28204994. DOI: $10.1007 / \mathrm{s} 00520-017-3613-\mathrm{z}$
Received October 9, 2021

Revised November 2, 2021

Accepted November 3, 2021 